\title{
Characterizing Hydrogeologic Heterogeneity Using Lithologic
}

\section{Data}

by

G. Flach

Westinghouse Savannah River Company

Savannah River Site

Aiken, South Carolina 29808

L. L. Hamm

M. K. Harris

P. A. Thaver

University of North Carolina at Wilmington

NC USA

J. S. Haselow

Svnesis Environmental, Inc.

SC USA

\section{A. D. Smits}

Sclence Applications International Corporation

GA USA .

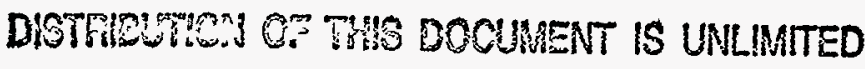

is

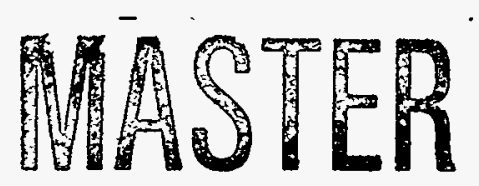

A document prepared for SEDIMENTOLOGICAL AND STRATIGRAPHIC CONTROLS ON AQUIFER

HETEROGENEITY at , , from - .

DOE Contract No. DE-AC09-89SR18035

This paper was prepared in connection with work done under the above contract number with the U.S. Department of Energy. By acceptance of this paper, the publisher and/or recipient acknowledges the U.S. Government's right to retain a nonexclusive, royalty-free license in and to any copyright covering this paper, along with the right to reproduce and to authorize others to reproduce all or part of the copyrighted paper. 


\section{DISCLAIMER}

This report was prepared as an account of work sponsored by an agency of the United States Government. Neither the United States Government nor any agency thereof, nor any of their employees, makes any warranty, express or implied, or assumes any legal liability or responsibility for the accuracy, completeness, or usefulness of any information, apparatus, product, or process disclosed, or represents that its use would not infringe privately owned rights. Reference herein to any specific commercial product, process, or service by trade name, trademark, manufacturer, or otherwise does not necessarily constitute or imply its endorsement, recommendation, or favoring by the United States Government or any agency thereof. The views and opinions of authors expressed herein do not necessarily state or reflect those of the United States Government or any agency thereof.

This report has been reproduced directly from the best available copy.

Available to DOE and DOE contractors from the Office of Scientific and Technical Information, P.O. Box 62, Oak Ridge, TN.37831; prices available from (615) 576-8401.

Available to the public from the National Technical Information Service, U.S. Department of Commerce, 5285 Port Royal Road, Springfield, VA 22161. 


\section{DISCLAMIER}

Portions of this document may be illegible in electronic image products. Images are produced from the best available original document. 


$$
\begin{gathered}
\text { Wsfc-ms-95-0497, } \\
\text { Rev.1 }
\end{gathered}
$$

Running head: Characterizing hydrogeologic heterogeneity using lithologic data

\author{
A METHOD FOR \\ CHARACTERIZING HYDROGEOLOGIC HETEROGENEITY \\ USING LITHOLOGIC DATA
}

GREGORY P. FLACH ${ }^{1}$, L. LARRY HAMM ${ }^{1}$, MARY K. HARRIS1,

PAUL A. THAYER ${ }^{2}$, JOHN S. HASELOW ${ }^{3}$ AND ANDREW D. SMITS 4

1 Westinghouse Savannah River Company, Aiken, South Carolina 29808

2 The University of North Carolina at Wilmington, Wilmington, North Carolina 28403

${ }^{3}$ Synesis Environmental, Inc., Aiken, South Carolina 29803

4 Science Applications International Corporation, Augusta, Georgia 30901

Key words and phrases: heterogeneity, three-dimensional interpolation, groundwater flow and contaminant transport modeling, hydrogeology 


\begin{abstract}
Large-scale $(>1 \mathrm{~m})$ variability in

hydraulic conductivity is usually the main

influence on field-scale groundwater flow

patterns and dispersive transport.

Incorporating realistic hydraulic conductivity

heterogeneity into flow and transport models

is paramount to accurate simulations,

particularly for contaminant migration.

Sediment lithologic descriptions and

geophysical logs typically offer finer spatial

resolution, and therefore more potential

information about site-scale heterogeneity,

than other site characterization data:
\end{abstract}

In this study, a technique for generating a heterogeneous, three-dimensional hydraulic conductivity field from sediment lithologic descriptions is presented. The approach involves creating a three-dimensional, finescale representation of mud (silt+clay) . percentage using a "stratified" interpolation algorithm. Mud percentage is then translated into horizontal and vertical conductivity using direct correlations derived from measured data and inverse groundwater flow modeling. Lastly, the fine-scale conductivity fields are averaged to create a coarser grid for use in groundwater flow and transport modeling.

The approach is demonstrated using a finite-element groundwater flow model of a Savannah River Site solid radioactive and hazardous waste burial ground. Hydrostratigraphic units in the area consist of fluvial, deltaic, and shallow marine sand, mud and calcareous sediment that exhibit abrupt facies changes over short distances. For this application, the technique improves estimates of large-scale flow patterns and dispersive transport. The conductivity fields mimic actual lithologic data providing a more realistic picture of subsurface heterogeneity. Field-observed, preferential pathways for contaminant migration are replicated in the simulations without the need to artificially create zones of high conductivity.

\section{INTRODUCTION}

Groundwater flow and especially contaminant transport can be affected by many physical, chemical and microbiological factors. Among these, large-scale ( $>1 \mathrm{~m}$ ) variability in hydraulic conductivity is the dominant influence on field-scale 
groundwater flow patterns and dispersive transport, with other factors introducing second-order effects (Brusseau, 1994). Incorporating hydraulic conductivity heterogeneity into flow and transport models is paramount to accurate simulations in most situations, particularly for contaminant migration. Sediment lithologic descriptions and down-hole geophysical logs typically offer finer spatial resolution, and therefore more potential information about heterogeneity, than most other site characterization data. However, these data do not provide direct information about hydrogeologic properties and can be viewed as "soft" hydrogeologic information. The emergence of powerful computing resources has enabled the routine use of spatiallydense, three-dimensional (3D) "soft" hydrogeologic data in 3D flow and transport models. Methods for supplementing "hard" hydrogeologic data (e.g., pump tests, slug tests, laboratory conductivity data), conventionally used to develop flow and transport models, with spatially-dense, 3D "soft" hydrogeologic data are the focus of this study. By utilizing widely available and relatively inexpensive core data, these methods should reduce model uncertainty and the amount of field-scale hydrogeologic data required.

Two key elements of these methods are 1) an algorithm for generating a complete 3D representation from discrete, spatiallyscattered field data, and 2) a method for translating "soft" data into hydraulic conductivity, and other necessary hydrogeologic parameters. Most articles in the literature focus on only one of these components. An exception is Lahm et al. (1995) who present a general procedure for estimating hydraulic conductivity from porosity (derived from geophysical logs) using a direct correlation, and generating a 3D conductivity field using a Bayesian updating/Cholesky decomposition stochastic approach. Below we review literature falling in the two categories above, emphasizing studies most relevant to the geology of the U.S. Department of Energy's (DOE) Savannah River Site (SRS) (Fig. 1).

\section{Interpolation Algorithms}

Several methods have been proposed for generating a complete $3 \mathrm{D}$ representation 
from discrete, spatially-scattered field data including, deterministic interpolation, kriging, indicator geostatistics, turning bands methods, inverse and inverse conditional analysis, fractal-based approaches, and sedimentological models. All of these approaches have been used to successfully interpolate data. Each has inherent strengths and weaknesses, which should be considered when selecting an algorithm for a particular application. Deterministic methods such as inverse distance weighting and spline interpolation are conceptually simple, straightforward to implement, and generally yield good 3D representations of data. However, these methods typically ignore known or inferred information about spatial correlation, which can be used to improve the fit. Also, the uncertainty in interpolated values is difficult to estimate. For these reasons, investigators have pursued geostatistical techniques over the last two decades.

Kriging (e.g., Journel and Huijbregts, 1978; Isaaks and Srivastava, 1989) originated from the mining industry as a geostatistical interpolation method that utilizes information on the covariance of variables in space, in addition to data values. Kriging offers an improvement over simple interpolation schemes in many instances and has been widely employed over the last decade or so. The method also provides the uncertainty associated with each interpolated value, which may be important information depending on the application. Although an improved fit can be achieved, the choices of variogram and underlying error distribution are subjective and can lead to a wide range of possible solutions. Also, traditional kriging assumes that the covariance field is stationary or weakly stationary (only dependent upon distance between points), which may not be an appropriate assumption. In this case, additional effort is required to transform the original variable into a stationary one. Like other methods, kriging often perforims poorly when there is a paucity of hard data. This is especially true for kriging methods that incorporate anisotropy (covariance dependent upon direction) to account for layering of sediments, for example.

Journel (1986) and Rubin and Journel (1991) attempted to overcome data 
Characterizing hydrogeologic heterogeneity using lithologic data

deficiencies by utilizing "soft" information, and developed the binary indicator method with kriging to generate 3D fields. Phillips and Wilson (1989) and Brannan and Haselow (1993) also developed methods based on geometrical description of the geological media and statistical functions to generate fields. These turning bands methods provide additional refinement to the kriging approach, but can be labor intensive.

Some natural processes are known to be fractal, and this observation has motivated recent investigations of fractal-based algorithms to generate 3D representations of geological systems. Hewett (1986) and Hewett and Behrens (1988) used fractal concepts to describe $3 \mathrm{D}$ geological systems with measurements of porosity from geophysical logs. Molz and Boman (1993) later applied the procedure to a hydraulic conductivity data base. Boman et al. (1995) concluded that while fractal-based methods are promising, their application requires further understanding and refinement. Some alternative methods generate $3 \mathrm{D}$ fields using knowledge of the physical processes of sediment deposition. For example, Webb (1994) developed a simulator to mimic a braided stream depositional environment and generate 3D fields. These methods show promise, but will require significantly more research to encompass the complex and varied depositional processes that occur during the formation of a hydrogeological unit.

Dagan (1985) proposed a method in which the 3D field is determined with the aid of an inverse solution of the groundwater flow equation. The method is termed a "conditional" or "unconditional" inverse simulation, depending upon whether measured data are honored in the interpolated field. Another inverse approach that has been proposed to generate 3D realizations is to solve the inverse problem for both the flow and transport equation to estimate the hydrogeologic properties of an aquifer (e.g., Sun and Yeh; 1990; Wagner and Gorelick, 1987). Hyndman et al. (1994) proposed refining this method using seismic data. However, solving the flow and transport equations simultaneously is nontrivial and requires more development. 
Additional research is needed to evaluate and understand 3D interpolation algorithms in a practical sense, as Boman et al. (1995) have done in evaluating inverse distance weighting, kriging and fractal-based methods for generating a 3D conductivity field. Their evaluation indicates that a simple deterministic approach involving successive inverse distance weighting interpolation by horizontal layer is the preferred approach, based on its relative simplicity and the absence of improved tracer test modeling results using the other methods. Based on the conclusion of Boman et al. (1995), a relatively simple deterministic interpolation method was chosen for this study.

Translation of "Soft" Data into Hydrogeologic

Parameters

Methods employed in the petroleum industry for relating intrinsic permeability to borehole geophysical data are described in Lake and Carroll (1986) and Flint and Bryant (1993): Lahm et al. (1995) recently reviewed several efforts to relate permeability to borehole geophysical data including Timur (1968), Croft (1971), Keys and MacCary (1971), Kelly (1977), Biella et al. (1983),
Doveton (1986), Wendt et al. (1986), Urish (1981), and Jorgensen (1989). They also evaluated three methods of estimating conductivity primarily from porosity, as applied to the Milk River aquifer in Alberta, Canada. Lahm et al. (1995) found that a direct correlation between conductivity and porosity produced a lower residual between the measured and predicted datasets than the methods of Urish (1981) and Jorgensen (1989).

Many predictive methods for estimating hydraulic conductivity from grain-size data have been proposed over the last several decades (Freeze and Cherry, 1979; Domenico and Schwartz, 1990). These methods are most reliable when applied to aquifer zones consisting of clean sand and gravel. Riha (1993) evaluated ten predictive equations as applied to Coastal Plain sediment beneath the SRS and found that none performed adequately. The methods evaluated were those of Hazen (1892), Kozeny-Carmen (in Carmen, 1937), Krumbein and Monk (1943), Harleman et al. (1963), Masch and Denny (1966), Beard and Weyl (1973), Puckett et al. (1985), Ahuja et al. (1989), Franzmeier (1991) 
and Jabro (1992). Riha (1993) developed a predictive equation from a small SRS data set, but that correlation has not been tested beyond the data used to develop the correlation.

Kegley et al. (1994) performed over 4000 minipermeameter tests of Tertiary-aged Coastal Plain sediments at the SRS and correlated the geometric mean of measured permeability for each stratigraphic unit within each well to mud fraction estimated by binocular microscope examination. The correlation coefficient $(r)$ of the expression is 0.92.

\section{Present Study}

For this study, borehole geophysical data are combined with information from microscopic core examinations to yield qualitative grain-size distribution information in the form of estimated percent gravel, sand, and mud. A general approach is presented for generating a heterogeneous, 3D hydraulic conductivity field from estimated mud fraction (silt + clay sized material). The mud fraction data are first interpolated onto a 3D Cartesian grid using the minimum-tension spline algorithm implemented in EarthVision ${ }^{\circledR}$ version 2.0

(Dynamics Graphics, Inc., Alameda, CA) with minimal "vertical influence" selected. This interpolation approach is analogous to the successive inverse distance weighting interpolation by horizontal layer scheme recommended by Boman et al. (1995), and is easily applied using EarthVision ${ }^{\circledR}$. The mud fraction grid is translated into horizontal and vertical conductivity fields using direct correlations of conductivity to mud fraction. The correlations are developed initially from laboratory data and adjusted through inverse groundwater flow modeling. Selection of a direct correlation approach is motivated and supported by Kegley et al. (1994) and Lahm et al. (1995). The fine-scale conductivity fields are then transferred to a coarser grid for use in groundwater flow modeling through arithmetic and harmonic àveraging. This method is demonstrated in a finiteelement groundwater flow model for a radioactive and hazardous waste burial ground at the Savannah River Site.

\section{SITE DESCRIPTION AND HYDROGEOLOGY}

The study area is located in the Upper Atlantic Coastal Plain physiographic 
province in southwestern South Carolina at the U.S. Department of Energy Savannah River Site (SRS) (Fig. 1). The SRS occupies approximately $800 \mathrm{~km}^{2}$ and was set aside in 1950 as a controlled area for the production of nuclear material for national defense, and specialized nuclear materials for medical and industrial purposes. The study area is located near the center of the SRS within the $40 \mathrm{~km}^{2}$ General Separations Area (GSA) (Fig. 1). This area is undergoing intense hydrogeological characterization for RCRA and CERCLA investigations. The focus of this study is the original solid radioactive and hazardous waste burial ground in the GSA. The burial ground received solid radioactive and hazardous waste from approximately 1952 to 1972 . Primary groundwater contaminants include tritium, trichloroethylene (TCE) and tetrachloroethylene (PCE). Groundwater plumes emanating from the burial ground are migrating to the south toward Fourmile Branch (Fig. 1).

The SRS is underlain by a southeastdipping wedge of unconsolidated and consolidated sediment consisting of sand, mud, limestone, and gravel, which range in age from early Late Cretaceous (Cenomanian) to Holocene (Fallaw and Price, 1995). This study involves the Tertiary-aged sediment, principally the Eocene to Miocene sequence (Fig. 2). The Gordon aquifer, the Gordon confining unit and the Upper Three Runs aquifer are the hydrostratigraphic units of interest (Fig. 2).

The Gordon aquifer consists of unconsolidated sand and clayey sand of the Congaree Formation and, where present, the sandy parts of the underlying Williamsburg Formation. The sand is yellowish to grayish orange in color and is subrounded to wellrounded, moderately to poorly sorted, and medium to coarse-grained. The Gordon confining unit separates the Gordon and Upper Three Runs aquifers and is lithostratigraphically equivalent tō the Warley Hill Formation. This unit is composed of fine-grained, silty and clayey sand, sandy clay and clay. The clay is stiff to hard and sometimes fissile. Zones of silicacemented sand and clay, and calcareous sediment are common.

The Upper Three Runs aquifer includes 
all sediment from the ground surface to the top of the Gordon aquifer.

Lithostratigraphically, the Upper Three Runs aquifer includes the Upland unit, Tobacco Road Sand, Dry Branch Formation, and Santee Formation (Fig. 2). The Upper Three Runs aquifer is divided by the "tan clay" confining zone into a "lower" aquifer zone and "upper" aquifer zone. The "lower" aquifer zone consists of a variety of lithologies including terrigenous sand and clay, calcareous skeletal sand, and sandy limestone. The "tan clay" confining zone contains light-yellowish tan to orange clay and sandy clay interbedded with clayey sand and sand. The "upper" aquifer zone is characterized by sand and clayey sand with minor intercalated clay layers. Gravelly layers are common.

Hydrogeological characterization of the study area indicates that groundwater contamination is primarily contained within the Upper Three Runs aquifer over a lateral distance of approximately one kilometer. Although contaminant transport takes place mainly within this single hydrostratigraphic unit, the aquifer exhibits considerable field- scale heterogeneity, as indicated by a wideranging lithology and physical characteristics depicted in Figure 3.

\section{METHODS}

Data from detailed, foot-by-foot descriptions of continuous drill core from 84 boreholes are utilized in this study. Figure 1 shows the areal distribution of the data in relation to the burial ground, and the selected numerical flow model domain. The core descriptions include data on core recovery; degree of induration; color; sedimentary structures; volume percent terrigenous gravel, sand, and mud; maximum and modal size of the terrigenous fraction; volume percent carbonate gravel, sand, and mud; volume percent cement; volume percent total carbonate sediment; sediment/rock name; grain sorting; volume percent porosity and dominant type; fossil types; and volume percent accessory constituents, including muscovite, glauconite, lignite, sulfides, and heavy minerals. The volume percent terrigenous gravel, sand, and mud data were used in generating 3D conductivity fields.

Figure 4 outlines the overall methodology used to generate heterogeneous hydraulic 
Characterizing hydrogeologic heterogeneity using lithologic data

conductivity fields from these lithologic descriptions. Mud fraction data are initially interpolated onto a 3D grid using an algorithm that preserves sharp vertical contrasts. The mud fraction grid is translated into horizontal $\left(\mathrm{K}_{\mathrm{h}}\right)$ and vertical conductivity $\left(\mathrm{K}_{\mathrm{v}}\right)$ fields using direct "correlations" of conductivity to mud fraction. Laboratory conductivity measurements on whole core and quantitative grain-size distribution data from sieve analyses are utilized as a guide for the development of the correlations. On the first pass, the correlations are based strictly on laboratory conductivity data. On subsequent passes, inverse flow modeling also influences the correlations through a feedback loop; that is, the correlations are adjusted to achieve better flow model results when compared to hydraulic head data and other targets. The fine-scale conductivity fields are transferred to the coarser groundwater flow model grid through arithmetic $\left(\mathrm{K}_{\mathrm{h}}\right)$ and harmonic $\left(\mathrm{K}_{\mathrm{v}}\right)$ averaging. The process is discussed below in greater detail.

Three-Dimensional Interpolation of Mud Fraction Data
Boman et al. (1995) have demonstrated that relatively simple interpolation concepts can be used to successfully generate heterogeneous 3D conductivity fields for flow and transport models. They employed what can be termed successive inverse distance weighting (IDW) interpolation by horizontal layer, or "stratified IDW" in their terminology. The idea is to conceptually divide the subsurface into horizontal layers of uniform thickness. These layers are arbitrary and do not necessarily conform to formation boundaries or other geologic features. Within each layer, two-dimensional inverse distance weighting is independently applied using only the subset of borehole data lying within that layer. With this stratified IDW approach, smoothing occurs in the horizontal plane while sharp vertical contrasts (if present) are preserved:

A similar effect can be achieved using the minimum-tension spline interpolation algorithm implemented in the EarthVision ${ }^{\circledR}$ software package (Version 2.0, Dynamics Graphics, Inc., Alameda, CA), by selecting a very small "vertical influence factor." The vertical influence factor is applied to data 
lying above and below the horizontal plane passing through the interpolation node of interest. By choosing a very small value, almost no weight is given to data above or below each interpolation node relative to data in the horizontal plane of that node.

In this study, the lithologic descriptions from the 84 boreholes depicted in Figure 1 were interpolated onto a $23 \times 23 \times 251$ grid of dimensions $3353 \mathrm{~m}(11,000 \mathrm{ft}) \times 3353 \mathrm{~m}$ $(11,000 \mathrm{ft}) \times 76 \mathrm{~m}(250 \mathrm{ft})$. The areal dimensions correspond to the solid line box in Figure 1. The areal resolution was uniformly set to $152 \mathrm{~m}(500 \mathrm{ft})$ while the vertical resolution was uniformly set to 0.30 $\mathrm{m}(1 \mathrm{ft})$, the same as the raw data. In all, 12,626 mud fraction data points were employed. A vertical influence factor of 0.01 was selected to preserve vertical contrasts. Interpolated values of mud fraction were constrained to fall within the physical range of 0 to 1 to remedy under- and over-shoots between or beyond data. In a few locations lacking measured data, pseudo-data were added as control points to minimize extrapolation errors. Figure 5 illustrates the portion of the resulting $3 \mathrm{D}$ mud fraction representation contained within the flow model areal domain (dashed box in Figure 1) and cropped by the ground surface. The lithologic heterogeneity of the subsurface hydrostratigraphic units is easily recognized and corresponds with hand-contoured lithofacies maps and cross-sections (Fig. 3) (Thayer et al., 1994). Note that the interpolation process has preserved horizontal stratification of the sediments. Conductivity. Versus Mud Fraction Correlations Laboratory measurements of horizontal and vertical conductivity for Tertiary-aged sediments at the SRS are available from a number of sources (Bledsoe et al., 1990; Riha, 1993; Kegley et al., 1994; Aadland et al., 1995) (Fig. 6). The data show an overall trend of decreasing conductivity with increasing mud fraction, but exhibit a great deal of scatter. Estimated mud fractions are availäble for the entire length of all cores, whereas, sieve data are available primarily for transmissive well screen zones ( 3 to $10 \mathrm{~m}$ ). In order to utilize the most data, a direct correlation between conductivity and estimated mud fraction was chosen instead of a grain-size distribution data correlation. Kegley et al. (1994) and 
Lahm et al. (1995) demonstrated success using this approach. The initial conductivitymud fraction correlations were developed based solely on the laboratory conductivity data. However, the resulting flow simulation did not adequately match hydraulic head, average recharge and stream gain targets. As such, the correlations were adjusted manually to improve flow results while maintaining consistency with the laboratory data. The stair-step functions shown in Figure 6 are the final outcome of this iterative flow model calibration process.

A stair-step functional form is chosen for two reasons. The interpolated mud fraction field shown in Figure 5 contains numerous regions where under- and over-shoots in the initial fit are clipped by EarthVision ${ }^{\circledR}$ to lie within the specified physical range of zero to one. These initial under- and over-shoots are located between sparsely distributed data and at the fringes of the data (i.e., extrapolation errors). As a result the interpolated mud fraction field contains an artificially large number of values at or near zero and one. The flat portions of the stairstep functions tend to alleviate this problem by assigning the same conductivity to all mud fraction values in the vicinity of zero and one, respectively. Secondly, the stairstep functions provide the analyst very simple and direct control over conductivity values during model calibration when compared to other potential functional forms. A disadvantage of the correlations is the presence of unrealistically abrupt changes in conductivity. This deficiency is not serious because the abruptness is effectively smoothed out when the conductivity fields are translated to the coarser flow model grid through the averaging process discussed below.

In order to reduce the degrees of freedom during calibration to a reasonable number, restrictions were invoked early in the process. The correlations were constrained such that the ratio of horizontal to vertical conductivity is three. This conductivity anisotropy ratio is suggested by the laboratory data of Bledsoe et al. (1990). Also, the junctions between steps of $0.1,0.25$, and 0.50 were held constant during final calibration. These choices yield four independent horizontal conductivity 
parameters spanning mud fraction ranges of 0.0 to $0.1,0.1$ to $0.25,0.25$ to 0.50 , and 0.50 to

1.0. The flow model calibration process in this study is analogous to that performed for a conventional "layer cake" model, with horizontal conductivities within mud fraction ranges taking the place of hydrostratigraphic unit conductivities (or zonal conductivities within a unit).

\section{Transfer to Flow Model Grid}

FACT, a variably-saturated 3D finiteelement flow and transport code developed in-house, was chosen for flow simulation. FACT is a derivative of the SAFT3D and VAM3DCG codes developed by HydroGeoLogic, Inc. (Huyakorn et al., 1991; Huyakorn and Panday, 1992). The code solves Richard's equations. FACT assumes the hydraulic conductivity tensor is aligned with the principle axes of the porous media and its diagonal values are specified at the element centroids. In this study the porous media is assumed to be isotropic in the two horizontal directions, but anisotropic with respect to its vertical direction.

To demonstrate the methodology, a finite-element mesh is selected that differs in extent, orientation, and spatial resolution from that of the mud fraction grid generated above. The extent of the flow model and its orientation relative to the mud fraction grid are shown in Figure 1 (dashed versus solid boxes). This domain captures the entire groundwater flow field from the burial ground to surface discharge at Fourmile Branch (Fig. 1), and places model boundaries near monitoring wells so that boundary conditions may be more accurately specified. The areal dimensions are $2060 \mathrm{~m}(6760 \mathrm{ft}) \times$ $1545 \mathrm{~m}$ (5070 ft). Eight-noded rectangular "brick" elements, that are restricted to deformations only in the vertical direction, are used. The elemental dimensions in the areal extent were uniformly set to $39.6 \mathrm{~m}$ (130 ft) per side. The top of the mesh conforms to the ground surface while the bottom of the mesh conforms to the top of the highly competent Meyers Branch confining system (Fig. 2). Element heights range from about $0.3 \mathrm{~m}(1 \mathrm{ft})$ to $6 \mathrm{~m}(20 \mathrm{ft})$ with an average value around $3 \mathrm{~m}(10 \mathrm{ft})$. The overall nodal dimensions of the flow grid are $53 \times 40 \times 30$ $(52 \times 39 \times 29$ elements). The selected flow grid is much coarser than the mud fraction 
grid in the vertical direction, but finer in the areal directions.

The process for translating the 3D mud fraction grid shown in Figure 5 into "composite" elemental conductivity defined over the $3 \mathrm{D}$ flow grid involves three steps and the creation of a fine-scale intermediate grid. First, while maintaining the $0.3 \mathrm{~m}(1 \mathrm{ft})$ vertical resolution of the mud fraction grid, mud fraction values were interpolated onto an intermediate grid whose areal grid points coincide with the element areal centroids of the flow grid. A natural bi-cubic spline interpolation was performed for each horizontal layer, independently. In the next step, mud fraction values defined on the resulting fine-scale intermediate grid were translated into "local" horizontal and vertical conductivities using the correlations shown in Figure 6. In the final step, these local conductivities on the fine-scale intermediate grid were vertically averaged over each finite-element (typically ten fine-scale layers per element). Figure 7 depicts the multi-step process discussed above starting from the fine-scale grid. During this last stage, composite conductivities (horizontal and vertical) were computed based on appropriate averaging (arithmetic and harmonic, respectively) where the local conductivities are assumed to reflect horizontal layering of aquifer materials that extend over the entire areal extent of each element. For a given finite-element these composite (horizontal and vertical) conductivities are expressed by

$$
\begin{aligned}
& K_{h}^{c o m p}=\frac{\sum_{i=i b}^{i=i t}\left(K_{h} \xi \Delta z\right)_{i}}{\sum_{i=i b}^{i=i t}(\xi \Delta z)_{i}} \\
& K_{v}^{c o m p}=\frac{\sum_{i=i b}^{i=i t}(\xi \Delta z)_{i}}{\sum_{i=i b}^{i t}\left(\xi \Delta z / K_{v}\right)_{i}}
\end{aligned}
$$


where

$$
\begin{array}{ll}
\text { ib } & \equiv \text { bottom fine-scale layer contained within element } \\
\text { it } & \equiv \text { top fine-scale layer contained within element } \\
\Delta z_{i} & \equiv \text { vertical height of } i^{\text {th }} \text { fine-scale layer } \\
\xi_{i} & \equiv \text { fraction of } i^{\text {th }} \text { fine-scale layer contained within element } \\
K_{h i} & \equiv \text { local horizontal conductivity of } i^{\text {th }} \text { fine-scale layer } \\
K_{v i} & \equiv \text { local vertical conductivity of } i^{\text {th }} \text { fine-scale layer } \\
K_{h}^{\text {comp }} & \equiv \text { composite horizontal conductivity of element } \\
K_{v}^{c o m p} & \equiv \text { composite vertical conductivity of element }
\end{array}
$$

The resulting horizontal and vertical conductivity fields are shown in Figures 8 and 9. In these figures, a wire-frame mesh outlines the finite-element flow grid and the finite-element centroidal conductivity values have been linearly interpolated. Both conductivity fields are seen to be highly heterogeneous in the upper part of the aquifer system. At the ground surface low conductivity zones in the top layer of elements in the upper far corner of each grid are defined in order to model low infiltration zones corresponding to industrial and capped areas.

\section{Recharge and Drain Boundary Conditions}

The present methodology permits low permeability zones to crop out at the surface as shown in Figure 5 at several locations and reflected in Figures 8 and 9. These detailed features, together with a complex, a priori unknown seepline, make conventional manual specification of model recharge and drainage conditions a complicated and tedious process. Where low permeability zones crop out, a lower infiltration rate should be specified compared to the average recharge to prevent computed hydraulic heads from exceeding ground elevation. Physically, most rainfall runs off low conductivity areas resulting in low infiltration and heads not exceeding ground elevation. Drain boundary 
conditions are needed wherever computed hydraulic head exceeds the ground elevation so that groundwater may properly discharge at the surface under these head conditions. Conversely, recharge boundary conditions should be specified wherever computed hydraulic head is below the ground surface. Because computed heads are not known beforehand, a manual trial-and-error process is conventionally required to determine whether a drain or recharge boundary condition is appropriate. If a recharge condition is needed, the appropriate local infiltration rate must also be specified.

Huyakorn et al. (1986) implemented an automated process for selecting a drain versus recharge boundary condition following Neuman et al. (1974) and Rulon (1984). The procedure involves a Picard iteration strategy imbedded in the flow code that switches between boundary condition types and also reduces infiltration as a seepline is approached. With this method convergence difficulties may arise for complex terrain and additional computational overhead is required to update boundary conditions during the iteration process.

The deficiencies expressed above can be eliminated by combining the concepts of recharge and drainage into a single boundary condition. The basic idea is that locally the surface is either recharging or draining the subsurface, and there should be a continuous transition between these conditions. Infiltration should occur for negative pressure head (water level below the ground surface) and aquifer discharge should occur for positive pressure head. Also, to be consistent with the continuity needs of the Newton-Raphson iterative solver employed in FACT, the overall function representing this "combined" recharge/drain boundary condition should be continuous in its first derivative.

Figure 10 presents a combined recharge/drain boundary condition that meets the above criteria. When the water level is well below the ground surface, 
recharge occurs at the maximum rate permitted locally. As the pressure head approaches zero, recharge is smoothly reduced to zero. For positive pressure head, the surface drains the aquifer at a rate proportional to the pressure head. To the left of the transition zone, the combined recharge/drain boundary condition is exactly the same as the conventional recharge boundary condition. To the right of the transition zone, the combined recharge/drain boundary condition is identical to a typical drain boundary condition. The transition zone reflects a non-linear region connecting two limiting linear boundary conditions. The mathematical formulation chosen for this function, as shown in Figure 10, is

$$
Q_{C}=\left\{\begin{array}{ccc}
Q_{R} & \text { for } & \psi \leq \frac{3}{2} \hat{\psi} \\
\frac{Q_{R}}{8}\left[7-2 x-x^{2}\right] & \text { for } & \frac{3}{2} \hat{\psi}<\psi<\frac{1}{2} \hat{\psi} \\
-M_{D} \Psi & \text { for } & \frac{1}{2} \hat{\psi} \leq \psi
\end{array}\right.
$$

where

$$
\begin{gathered}
\psi=h-z_{c} \\
Q_{R}=A_{D} R_{\max } \\
M_{D} \equiv A_{D}\left(\frac{K}{b}\right)_{D} \\
x \equiv 2\left(\frac{\hat{\psi}-\psi}{\hat{\psi}}\right) \\
\hat{\psi} \equiv-\frac{Q_{R}}{M_{D}}
\end{gathered}
$$

and

$h \equiv$ hydraulic head

$z_{c} \equiv$ elevation of combination boundary condition 
$Q_{c} \equiv$ volumetric source or sink from combined effects of recharge and drainage

$R_{\max } \equiv$ maximum local recharge ( $43.2 \mathrm{~cm} /$ year in this study)

$\psi \equiv$ pressure head

$A_{D} \equiv$ area available for recharge and drainage (geometric area)

$(\mathrm{K} / \mathrm{b})_{\mathrm{D}} \equiv$ leakance coefficient (18.2 year $^{-1}$ in this study).

Equation (3) represents a two parameter model requiring the specification of the maximum local recharge rate $\left(R_{\max }\right)$ and the surface leakance coefficient $(K / b)_{D}$. The level of ponding along a seepage face can be adjusted by varying the magnitude of the surface leakance coefficient. Equation (3) is applied at every node over the entire top surface of the flow model in the present study. Seepage faces are automatically established during the iterative solution of the non-linear flow and boundary condition equations.

FLOW MODEL RESULTS AND DISCUSSION

FACT flow model results for the SRS burial ground are shown in Figures 11a and 12a. The results were generated from the optimal synthetic conductivity fields depicted in Figures 8 and 9. The root-meansquare residual between steady-state model and time-average measured hydraulic heads is $1.0 \mathrm{~m}$ ( $3 \mathrm{ft})$. Figure 11a shows 3D pathlines originating from the burial ground that have been projected onto a two-dimensional horizontal plane overlaying water saturation at the top surface. The seeplines surrounding Fourmile Branch conform closely to fieldobserved locations. As illustrated, groundwater pathlines originating from the burial ground converge into a preferred pathway that terminates at a small tributary to Fourmile Branch, consistent with contaminant monitoring data. In addition, local convergence of pathlines is observed in Figure 11a indicating the presence of finerscale preferred pathways. Figure 12 a shows $3 \mathrm{D}$ pathlines projected onto the cross-section $B-B^{\prime}$ in Figure 11a with mud fraction as the background. This cross-section coincides with the preferred pathway for groundwater flow from the burial ground and highlights vertical flow patterns. The example pathlines reveal a complex flow field resulting from 
heterogeneities incorporated into the conductivity field. Figure 12a shows contaminant migration from the burial ground can be expected to follow multiple distinct pathways within the same aquifer, corresponding to regions of low mud content.

For comparison, a conventional "layercake" flow model was created by assigning a uniform conductivity to each hydrostratigraphic unit. The results are displayed in Figures $11 \mathrm{~b}$ and 12b. The models exhibit significantly different largescale flow patterns, despite having similar average conductivities and yielding similar overall hydraulic head residuals ( $1.2 \mathrm{~m}$ r.m.s. for the homogeneous layer model). As shown in Figure 11a for the heterogeneous model, groundwater flows westward in the eastern portion of the burial ground and then flows southward at the west end.

Contaminant monitoring at perimeter wells confirms this overall flow pattern. Westward flow through the burial ground in the heterogeneous model reflects high mud content beneath the entire east end of the burial ground, parts of which are visible in
Figure 5. The conventional "layer cake" model could not be made to behave in a similar manner for laterally homogeneous properties, and indicated that groundwater flow is mostly to the south throughout the entire burial ground (Fig. 11b). As shown in Figure 12a, groundwater beneath the burial ground in the heterogeneous model flows southward to Fourmile Branch, consistent with monitoring data that indicates a groundwater flow divide just north of the burial ground. The homogeneous model does not account for the high mud content along the northern edge of the burial ground (Figs. 12a, b) and allows some groundwater to flow northward. The homogeneous model can certainly be improved by manually creating zones of differing $\mathrm{K}_{h} / \mathrm{K}_{\mathrm{v}}$ and/or additional layers to reflect the lithologic data, as is typically done. Results similār to those produced using the present methodology can also be obtained with sufficient detail and effort. In this case, the present automated technique offers a substantial savings in labor, more so than improved results. A second probable benefit of the heterogeneous model is the presence of 
multiple parallel pathways available for contaminant transport, as noted above and shown in Figure 12a. As discussed by Brusseau (1994) for example, contaminant dispersion is enhanced by aquifer heterogeneities at all scales. Heterogeneity produces a varying velocity field that transports portions of the contaminant plume at different rates. Heterogeneity not explicitly incorporated into the flow and transport model through the conductivity field must be accounted for through a separate mechanical dispersion term. The dispersivity value in this term is empirical and scale-dependent, and requires extensive monitoring data to define accurately. Finescale flow and transport models that capture as much aquifer heterogeneity as possible can reduce the magnitude and importance of the empirical dispersion term, leading to more accurate and reliable predictions. To investigate this point, transport simulations were performed for each model by placing a tracer concentration within the burial ground. Unfortunately, a direct, quantitative comparison of the conventional and heterogeneous models proved unfeasible, due to the significant differences in largescale flow patterns exhibited by the models, which masked differences in mechanical dispersion. A contributing factor is the relatively coarse resolution of the model grid, which produces large (masking) numerical dispersion and enables only a modest potential increase in mechanical dispersion.

\section{ASSESSMENT OF METHODOLOGY}

The methodology presented here has proven effective in generating a heterogeneous conductivity field for a SRS burial ground flow and transport model. The model conductivity values were determined from actual lithologic data, providing a more realistic picture of subsurface heterogeneity compared to traditional modeling approaches that produce a small number of relatively homogeneous layers. The approach improves large-scale flow patterns and dispersive transport compared to conventional methods. Preferential pathways for contaminant migration, inferred from field observations, are replicated in the model without the need to artificially create zones of high conductivity. The concepts are general and can be applied 
to other sites. The resulting conductivity fields may be used with other finite-element or finite-difference groundwater codes. Nevertheless, improvements and extensions can and should be considered.

As evidenced by large data scatter in Figure 6, there is much room for improvement in translating lithologic information into hydraulic conductivity. Utilizing additional information about grain size distribution would help, but, the experience of Riha (1993) suggests that additional factors such as cementation, pore size distribution, bedding type, etc. should be considered as well.

It would be beneficial to incorporate laboratory conductivity measurements more directly into the process for generating a conductivity field. Presently, these data have only a weak influence on the final conductivity field through the conductivity versus mud fraction correlation (i.e., individual data points in Figure 6 have little effect on the correlation). The same can be said of conductivity information derived from slug and pump tests, for example. One solution would be to omit the mud fraction interpolation step, translate borehole mud fraction data to conductivity, augment these data with laboratory and in situ conductivity measurements, and interpolate the composite conductivity data set onto a 3D grid. Then, laboratory and in situ conductivity measurements would have a strong local effect on the interpolated conductivity field, in addition to a global effect.

The interpolated mud fraction field displayed in Figure 5 appears to underestimate confining zone continuity. There are clay intervals in adjacent cores that are slightly offset vertically and unconnected in the model; in reality, we believe these should be connected. The "stratified" interpolation algorithm tends to not connect these intervals because they lie within different horizontal gridding layers. This problem is alleviated to some extent by vertical averaging during the transfer of finescale conductivity to the flow model grid. Also, harmonic averaging of vertical conductivities assumes perfect horizontal continuity within a grid element and slightly counteracts underestimation of continuity between elements. The conformal gridding 
option in EarthVision ${ }^{\circledR}$ could be used to achieve higher confining zone continuity by incorporating known variations in dip of strata into the gridding process. Selecting a coarser vertical resolution for the interpolated grid would increase interconnectedness, as would a larger vertical influence factor. These options would tend to blur vertical contrasts however, leaving conformal gridding as the preferred approach.

\section{CONCLUSIONS}

Based on the flow modeling results of this study we can conclude:

(1) Fine-scale, heterogeneous, hydraulic conductivity fields can be successfully generated directly from lithologic data using the general methods described herein.

(2) These hydraulic conductivity fields appear to provide a more realistic picture of subsurface hydrologic heterogeneity than conventional "layer cake" modeling approaches.

(3) The approach improves large-scale flow patterns and dispersive transport in groundwater modeling. For the SRS burial ground application, field-observed, preferential pathways for contaminant migration are replicated without the need to artificially create zones of high conductivity. ACKNOWLEDGMENTS

This work was supported by Westinghouse Savannah River Company under U. S. Department of Energy Contract No. DE-AC09-89SR18035. We thank Dr. Robert Ehrlich for reviewing a draft of the manuscript.

\section{- REFERENCES}

AADLAND, R. K., GELLICI, J. A., AND THAYER, P. A., 1995, Hydrogeologic framework of west-central South Carolina: South Carolina Department of Natural Resources, Water Resources Division Report 5, 200 p. +47 plates. AHUJA, L. R., CASSEL, D. K., BRUCE, R. R., AND BARNES, B. B., 1989, Evaluation of spatial distribution of hydraulic conductivity using effective porosity data: Soil Science, v. 148, p. 404-411.

BEARD, D. C. AND.WEYL, P.K.K., 1973, Influence of texture on porosity and permeability of unconsolidated sand: American Association of Petroleum Geologists Bulletin, v. 57, p. 349-369. 
BIELLA, G., LOZEJ, A., AND TABACCO, I., 1983, Experimental study of some hydrogeological properties of unconsolidated porous media: Ground Water, v. 21, p. 741-751.

BLEDSOE, H. W., AADLAND, R. K., AND SARGENT, K. A., 1990, Baseline hydrogeologic investigation - summary report (U): Aiken, S.C., Westinghouse Savannah River Company Report WSRCRP-90-1010, 40 p. + appendices.

BOMAN, G. K., MOLZ, F. J., GUVEN, O., 1995, An evaluation of interpolation methodologies for generating threedimensional hydraulic property distributions from measured data: Ground Water, v. 22, p. 247-258.

BRANNAN, J. R. AND HASELOW, J. S., 1993, Compound random field models of multiple scale hydraulic conductivity: Water Resources Research, v. 29, p. 365372.

BRUSSEAU, M. L., 1994, Transport of reactive contaminants in heterogeneous porous media: Reviews of Geophysics, v. 32, p. 285-313.

CARMEN, P. C., 1937, Fluid flow through granular beds: Transactions - Institution of Chemical Engineers, London, v. 15, p. 150-156.

CROFT, M. G., 1971, A method of calculating permeability from electric logs: U.S. Geological Survey Professional Paper 750-B, p. B265-B269.

DAGAN, G., 1985, Stochastic modeling of groundwater flow by unconditional and conditional probabilities: the inverse problem: Water Resources Research, v. 21, p. 65-72.

DOMENICO, P. A. AND SCHWARTZ, F. W., 1990, Physical and chemical hydrogeology: New York, John Wiley \& Sons, $824 \mathrm{p}$.

DOVETON, J. H., 1986, Log analysis of subsurface geology, concepts and computer methods: New York, John Wiley \& Sons, 273 p.

FALLAW, W. C. AND PRICE, V., 1995, Stratigraphy of the Savannah River Site and vicinity: Southeastern Geology, v. 35, p. 21-58.

FLINT, S. S. AND BRYANT, I. D., EDS., 1993, The geological modeling of hydrocarbon reservoirs and outcrop analogues: 
International Association of

Sedimentologists, Special Publication 15,

Oxford, Blackwell Scientific Publications, $269 \mathrm{p}$.

FRANZMEIER, D. P., 1991, Estimation of hydraulic conductivity from effective porosity data for some Indiana soils: Soil Science Society of America Journal, v. 55, p. 1801-1803.

FREEZE, R. A. AND CHERRY, J. A., 1979, Groundwater: Englewood Cliffs, Prentice-Hall, 604 p.

HARLEMAN, D. R. F., MELHORN, P. F., AND

RUMER, R. R., JR., 1963, Dispersionpermeability correlation in porous media: Journal of the Hydraulics Division, Proceedings of the American Society of Civil Engineers, v. 89, p. 67-85.

HAZEN, A., 1892, Some physical properties of sands and gravels with special reference to their use in filtration: Lawrence, Mass., 24th Annual Report of the State Board of Health of Massachusetts for 1892, $24 \mathrm{p}$.

HEWETT, T. A., 1986, Fractal distributions of reservoir heterogeneity and their influence on fluid transport, SPE Paper 15386 presented at the 1986 SPE Annual
Technical Conference and Exhibition, New Orleans.

HEWETT, T. A. AND BEHRENS, R. A., 1988, Conditional simulation of reservoir heterogeneity with fractals, SPE Paper 18326 presented at the 63rd Annual Technical Conference of the Society of Petroleum Engineers in Houston, Texas, October 2-5, 1988.

HUYAKORN, P. S. AND PANDAY, S., 1992, VAM3DCG - variably saturated analysis model in three-dimensions with preconditioned conjugate gradient matrix solvers; documentation and user's guide; version 2.4: Herndon, Virginia, HydroGeoLogic, Inc., 274 p.

HUYAKORN, P. S., PANDAY, S., AND BIRDIE, T., 1991, SAFT3D; Subsurface analysis finite element model for flow and transport in 3 dimensions; versiōon 1.3; documentation and user's guide: Herndon, Virginia, HydroGeoLogic, Inc., $288 \mathrm{p}$.

HUYAKORN, P. S., SPRINGER, E. P., GUVANASEN, V., AND WADSWORTH, T. D., 1986, A three-dimensional finiteelement model for simulating water flow 
in variably saturated porous media:

Water Resources Research, v. 22, p. 1790-

1808.

HYNDMAN, D. W., HARRIS, J. M., AND

GORELICK, S. M., 1994, Coupled seismic

and tracer test inversion for aquifer

property characterization: Water

Resources Research, v. 30, p. 1965-1977.

ISAAKS, E. H. AND SRIVASTAVA, R. M., 1989,

Applied geostatistics: New York, Oxford

University Press, $561 \mathrm{p}$.

JABRO, J. D., 1992, Estimation of saturated

hydraulic conductivity of soils from

particle size distribution and bulk

density: Transactions of the American

Society of Agricultural Engineers, v. 35, p.

$557-560$.

JORGENSEN, D. G., 1989, Using geophysical

logs to estimate porosity, water

resistivity, and intrinsic permeability: $U$.

S. Geological Survey Water-Supply Paper 2321,24 p.

JOURNEL, A. G., 1986, Nonparametric estimation and qualitative information The soft kriging approach: Mathematical Geology, v. 15, p. 268-286.
JOURNEL, A. G. AND HUIJBREGTS, C. J., 1978, Mining geostatistics: New York, Academic Press, 600 p.

KEGLEY, W. P., FALLAW, W. C., SNIPES, D.

S., BENSON, S. M., AND PRICE, V., JR., 1994, Textural factors affecting

permeability at the MWD well field,

Savannah River Site, Aiken, South

Carolina: Southeastern Geology, v. 34, p.

139-161.

KELLY, W. E., 1977, Geoelectric sounding for estimating aquifer hydraulic

conductivity: Ground Water, v. 15, p. 420425.

KEYS, S. W. AND MACCARY, L. M., 1971, Application of borehole geophysics to water-resources investigations: U.S. Geological Survey Techniques of WaterResources Investigations, Book 2, 123 p. KRUMBEIN, W. C. AND MONK, G.D., 1943, Permeability as a function of the size parameters of sedimentary particles: American Institute of Mining and Metallurgical Engineers, Technical Publication 1492, p. 153-163.

LAHM, T. D., BAIR, E. S., AND SCHWARTZ, F. W., 1995, The use of stochastic 
simulations and geophysical logs to

characterize spatial heterogeneity in

hydrogeologic parameters: Mathematical

Geology, v. 27, p. 259-278.

LAKE, L. W. AND CARROLL, H. B., JR., EDS., 1986, Reservoir characterization: Orlando, Academic Press, 659 p.

MASCH, F. D. AND DENNY, K. J., 1966, Grain

size distribution and its effect on the permeability of unconsolidated sands:

Water Resources Research, v. 2, p. 665-

677.

MOLZ, F. J. AND BOMAN, G. K., 1993, A

fractal-based stochastic interpolation scheme in subsurface hydrology: Water

Resources Research, v. 29, p. 3769-3774.

NEUMAN, S. P., FEDDES, R. A., AND

BRESLER, E., 1974, Finite element

simulation of flow in saturated -

unsaturated soils considering water

uptake by plants: Report for Project ALO-

5WC-77, Hydrodynamics and Hydraulic

Engineering Laboratory, Technion, Hafia,

Israel, $104 \mathrm{p}$.

PHILLIPS, F. M. AND WILSON, J. L., 1989, An approach to estimating hydraulic conductivity spatial correlation scales using geological characteristics: Water

Resources Research, v. 25, p. 141-143.

PUCKETT, W. E., DANE, J. H., AND HAJEK, B.

F., 1985, Physical and mineralogical data

to determine soil hydraulic properties:

Soil Science Society of America Journal, v. 49, p. 831-836.

RIHA, B. D., 1993, Predicting saturated

hydraulic conductivity for

unconsolidated soils from commonly

measured textural properties: M.S.

Thesis, Clemson University, Clemson,

S.C., 87 p.

RUBIN, Y. AND JOURNEL, A. G., 1991,

Simulation of non-Gaussian space

random functions for modeling transport

in groundwater: Water Resources

Research, v. 27, p. 1711-1721.

RULON, J., 1984, The development of

multiple seepage faces along --

heterogeneous hillsides: Ph.D. Thesis,

University of British Columbia,

Vancouver, Canada, $161 \mathrm{p}$.

SUN, N.-Z., AND YEH, W. W.-G., 1990,

Coupled inverse problems in

groundwater modeling, 1, Sensitivity

analysis and parameter identification: 
Water Resources Research, v. 26, p. 25072525.

THAYER, P. A., SMITS, A. D., HARRIS, M. K., AMIDON, M. B., AND LEWIS, C. M., 1993, Hydrostratigraphic maps of the General Separations Area (GSA), Savannah River Site (SRS), Aiken, South Carolina, Phase II (U): Aiken, S. C., Westinghouse Savannah River Company Report WSRC-RP-94-40, 86 p. + appendices.

TIMUR, A., 1968, An investigation of permeability, porosity, and residual water saturation relationships for sandstone reservoirs: Log Analyst, v. 9, p. 8-17.

URISH, D. W., 1981, Electrical resistivityhydraulic conductivity relationships in glacial outwash aquifers: Water Resources Research, v. 17, p. 1401-1408.
WAGNER, B. J., AND GORELICK, S. M., 1987, Optimal groundwater quality management under parameter uncertainty: Water Resources Research, v. 23, p. 1162-1174.

WEBB, E. K., 1994, Simulating the threedimensional distribution of sediment units in braided-stream deposits: Journal of Sedimentary Research, section B, v. 64, p. 219-231.

WENDT, W.A., SAKURAI, S., AND NELSON, P. H., 1986, Permeability prediction from well logs using multiple regression, in Lake, L. W., and Carroll, H. B., Jr. eds., Reservoir Characterization: Orlando, Academic Press, p. 181-221. 


\section{FIGURE CAPTIONS}

FIG. 1. - Location map of the original Savannah River Site burial ground showing the flow model domain and available sediment lithologic descriptions from 84 wells.

FIG. 2.-Lithostratigraphic and hydrostratigraphic nomenclature at the SRS (modified from Aadland et al., 1995).

FIG. 3. -Lithostratigraphic and hydrostratigraphic cross-section A-A' (Fig. 1).

FIG. 4.-Flowchart summarizing the methodology for creating a heterogeneous conductivity field from sediment lithologic descriptions.

FIG. 5.-Three-dimensional mud fraction variation within the flow model domain (Fig. 1) generated with EarthVision ${ }^{\circledR}$ 's minimum tension $3 D$ gridding algorithm and a vertical influence factor of 0.01 . A total of 12626 mud fraction values from the 84 cores depicted in Figure 1 were interpolated.

FIG. 6.-Hydraulic conductivity as a function of mud fraction. The data represent laboratory measurements of conductivity from undisturbed core samples and mud fraction measured by sieve analysis. The stair-step correlation line is the result of comparison to the data shown and inverse flow modeling. a) horizontal conductivity, b) vertical conductivity.

FIG. 7.-Process for translating the fine-scale mud fraction grid into the coarser-scale flow model conductivity grid.

FIG. 8.-Three-dimensional horizontal conductivity distribution on the flow model finiteelement mesh.

FIG. 9. - Three-dimensional vertical conductivity distribution on the flow model finiteelement mesh. 
FIG. 10.-Combined recharge/drain boundary condition applied over the entire top surface of the flow model finite-element mesh.

FIG. 11.-Three-dimensional pathlines originating from the SRS burial ground projected onto a two-dimensional plane overlaying water saturation. Conductivity field a) depicted by Figs. 8 and 9, b) based on assumption of homogeneous aquifer/aquitard layers.

FIG. 12.-Three-dimensional pathlines projected onto cross-section B-B' in Figure 11 with mud fraction as the background. Conductivity field a) depicted by Figs. 8 and 9, b) based on assumption of homogeneous aquifer/aquitard layers. 


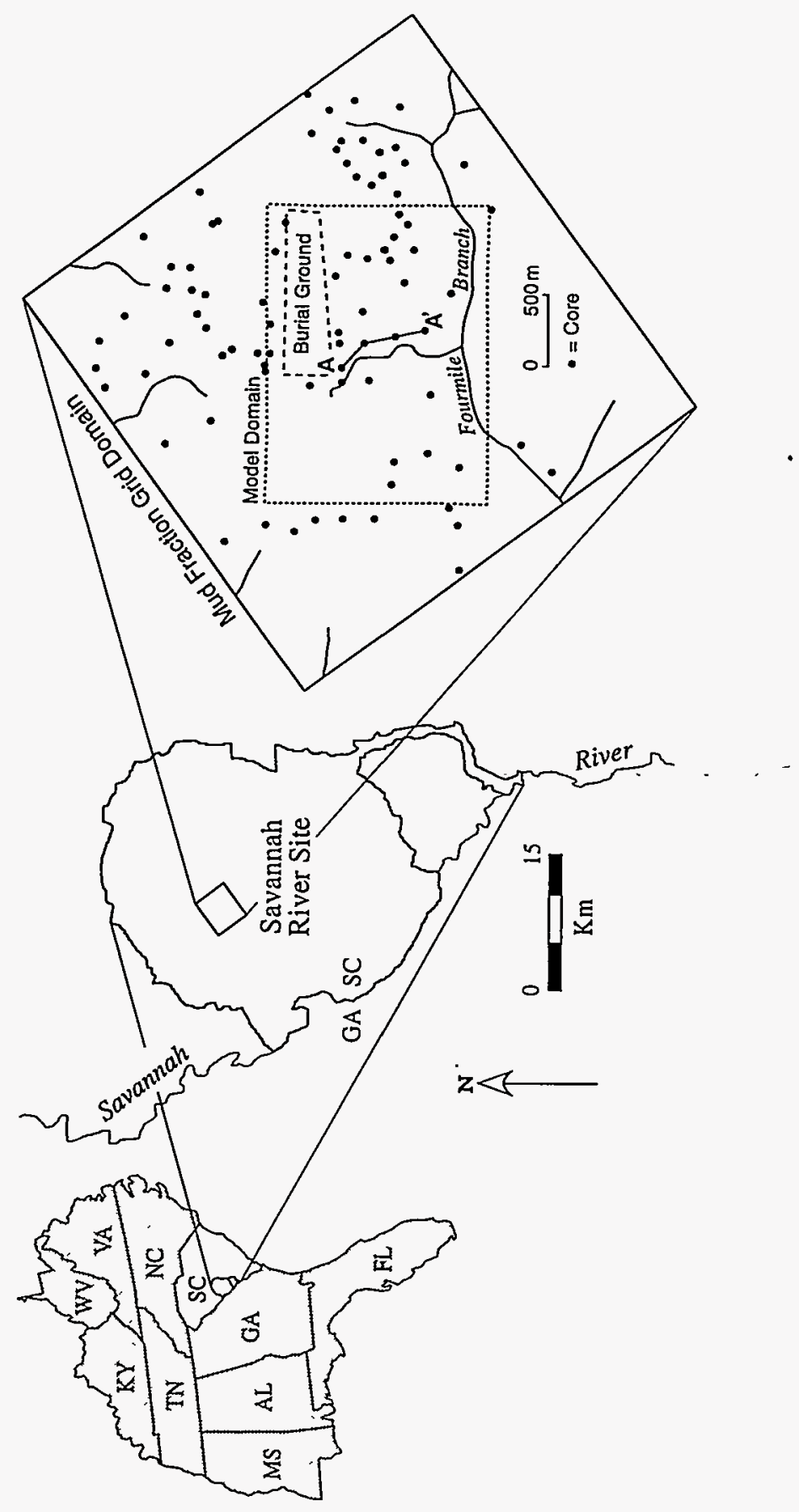




\begin{tabular}{|c|c|c|c|c|c|c|}
\hline Epoch & \multirow{2}{*}{\multicolumn{3}{|c|}{$\begin{array}{c}\text { Rock-stratigraphic unit } \\
\text { Upland unit }\end{array}$}} & \multicolumn{3}{|c|}{ Hydrogeologic unit } \\
\hline$\curvearrowright$ & & & & \multirow{5}{*}{ 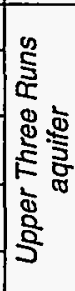 } & \multirow{3}{*}{$\begin{array}{l}\text { "upper" aquifer } \\
\text { zone }\end{array}$} & \multirow{7}{*}{ 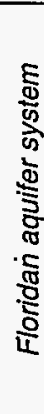 } \\
\hline \multirow{6}{*}{ 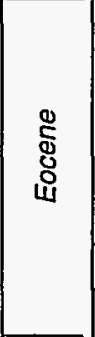 } & \multirow{3}{*}{$\frac{\stackrel{0}{0}}{\stackrel{0}{ \pm}}$} & \multicolumn{2}{|c|}{ Tobacco Road Sand } & & & \\
\hline & & \multirow{2}{*}{$\begin{array}{c}\text { Dry } \\
\text { Branch } \\
\text { Fm. }\end{array}$} & \multirow{2}{*}{$\begin{array}{c}\text { Inwinton } \\
\text { Sand Mbr. } \\
\text { Griffins } \\
\text { Landing Mbr. }\end{array}$} & & & \\
\hline & & & & & "lower" aquifer & \\
\hline & \multicolumn{3}{|c|}{ Santėe Formation } & & & \\
\hline & \multicolumn{3}{|c|}{ Warley Hill Formation } & \multicolumn{2}{|c|}{ Gordon confining unit } & \\
\hline & \multicolumn{3}{|c|}{ Congaree Formation } & \multicolumn{2}{|c|}{ Gordon aquifer } & \\
\hline \multirow{2}{*}{$\begin{array}{l}0 \\
8 \\
8 \\
\frac{8}{\pi} \\
0\end{array}$} & \multicolumn{3}{|c|}{ Williamsburg Formation } & \multirow{2}{*}{\multicolumn{3}{|c|}{$\begin{array}{l}\text { Meyers Branch } \\
\text { confining system }\end{array}$}} \\
\hline & \multicolumn{3}{|c|}{ Ellenton Formation } & & & \\
\hline
\end{tabular}




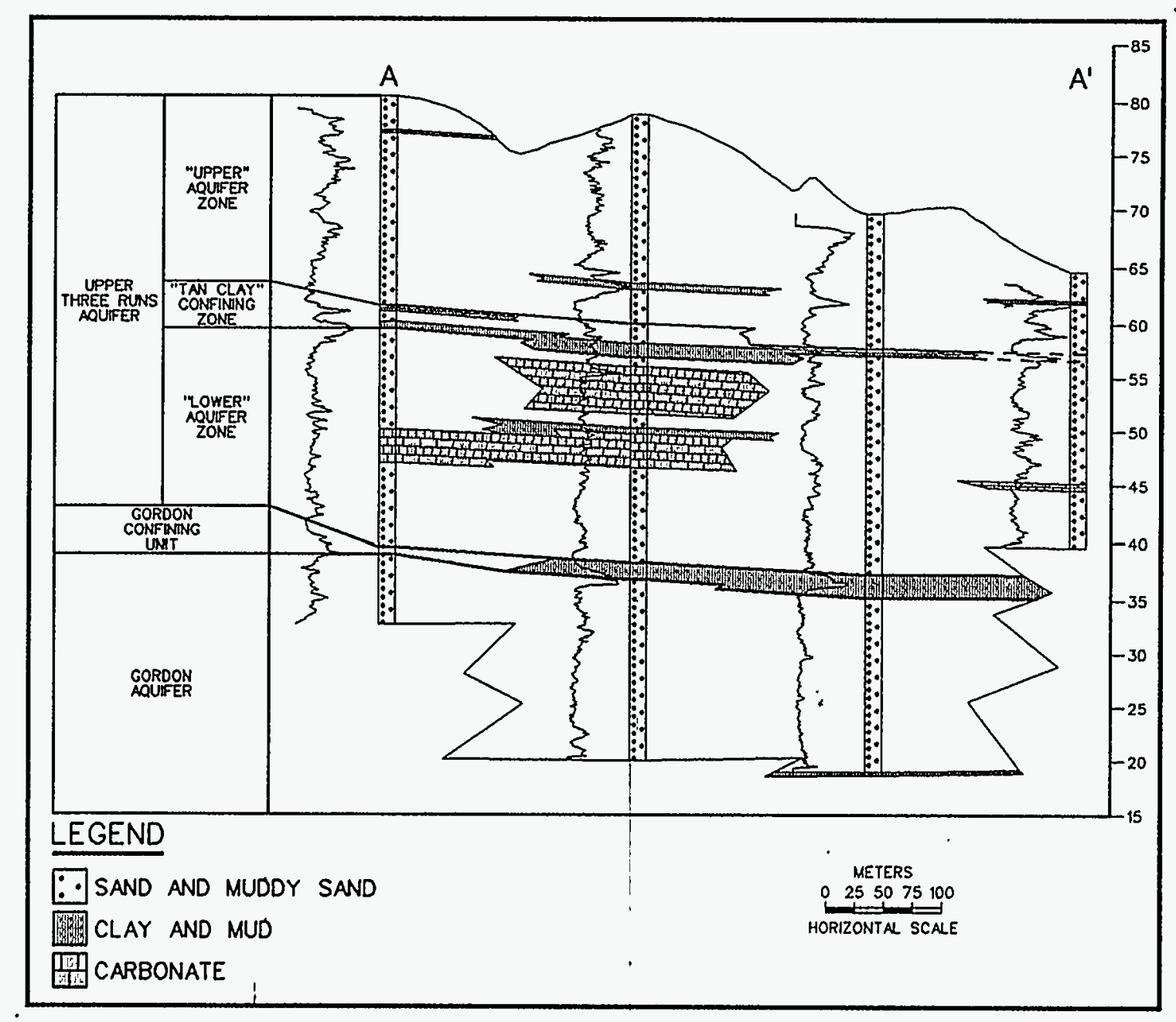




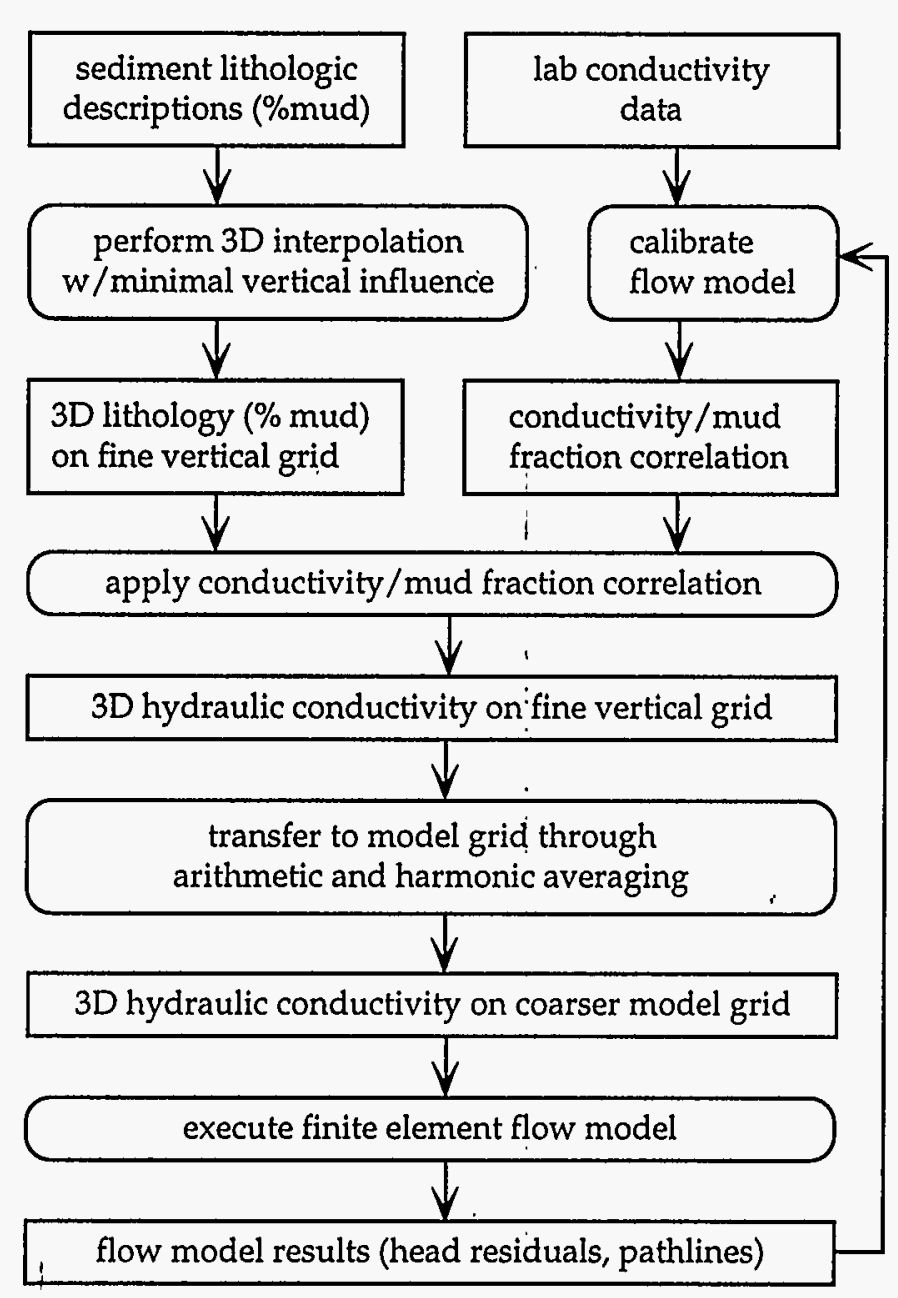




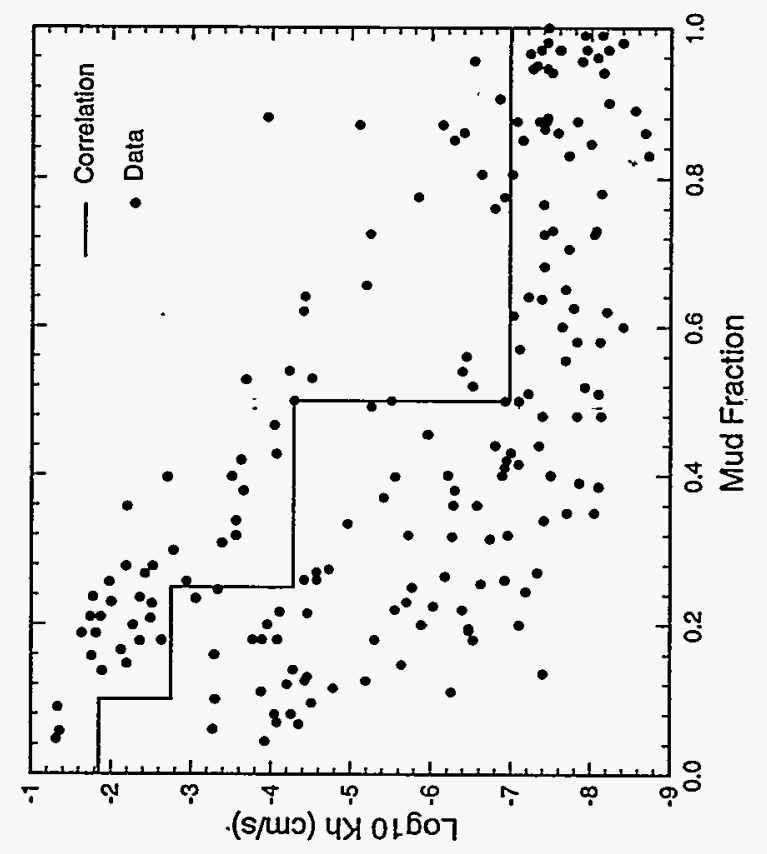




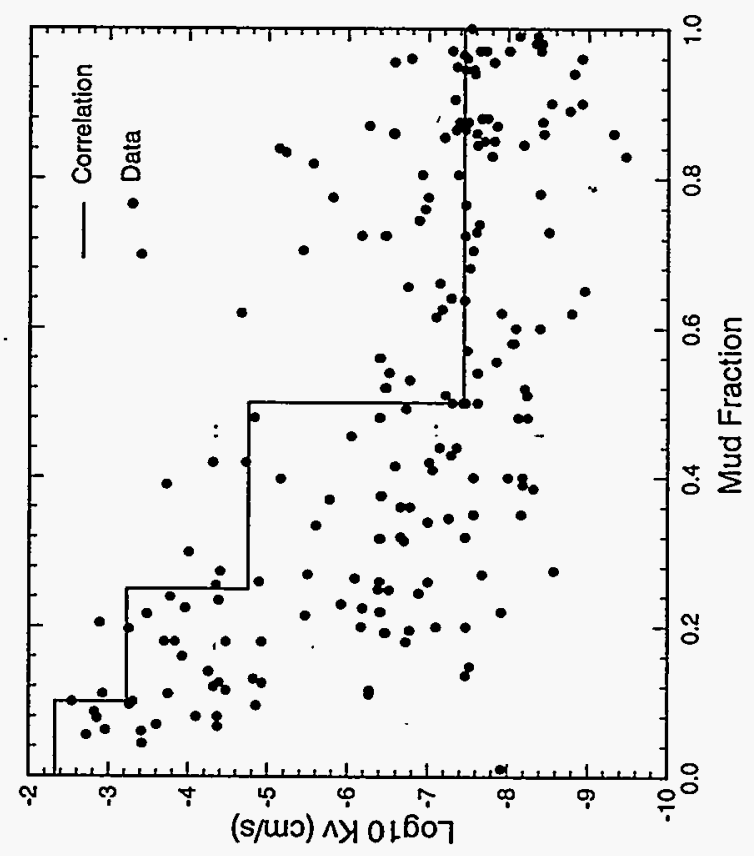




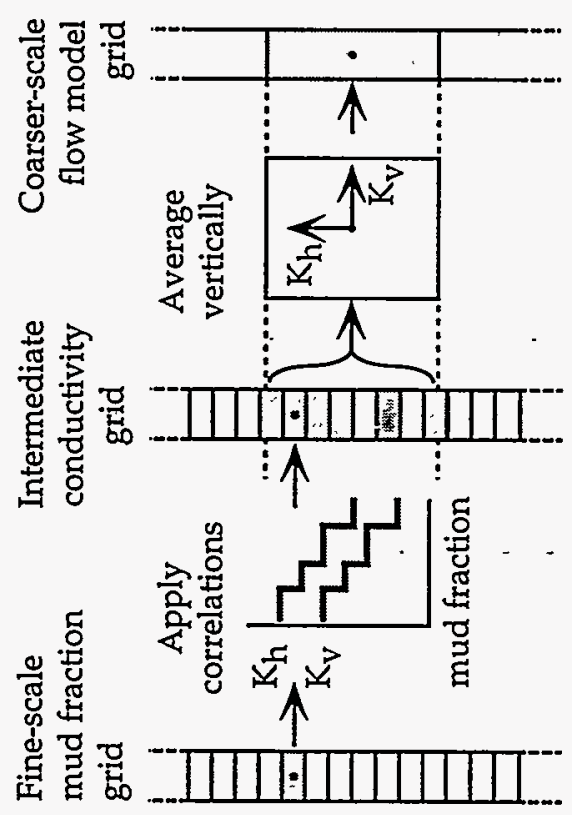




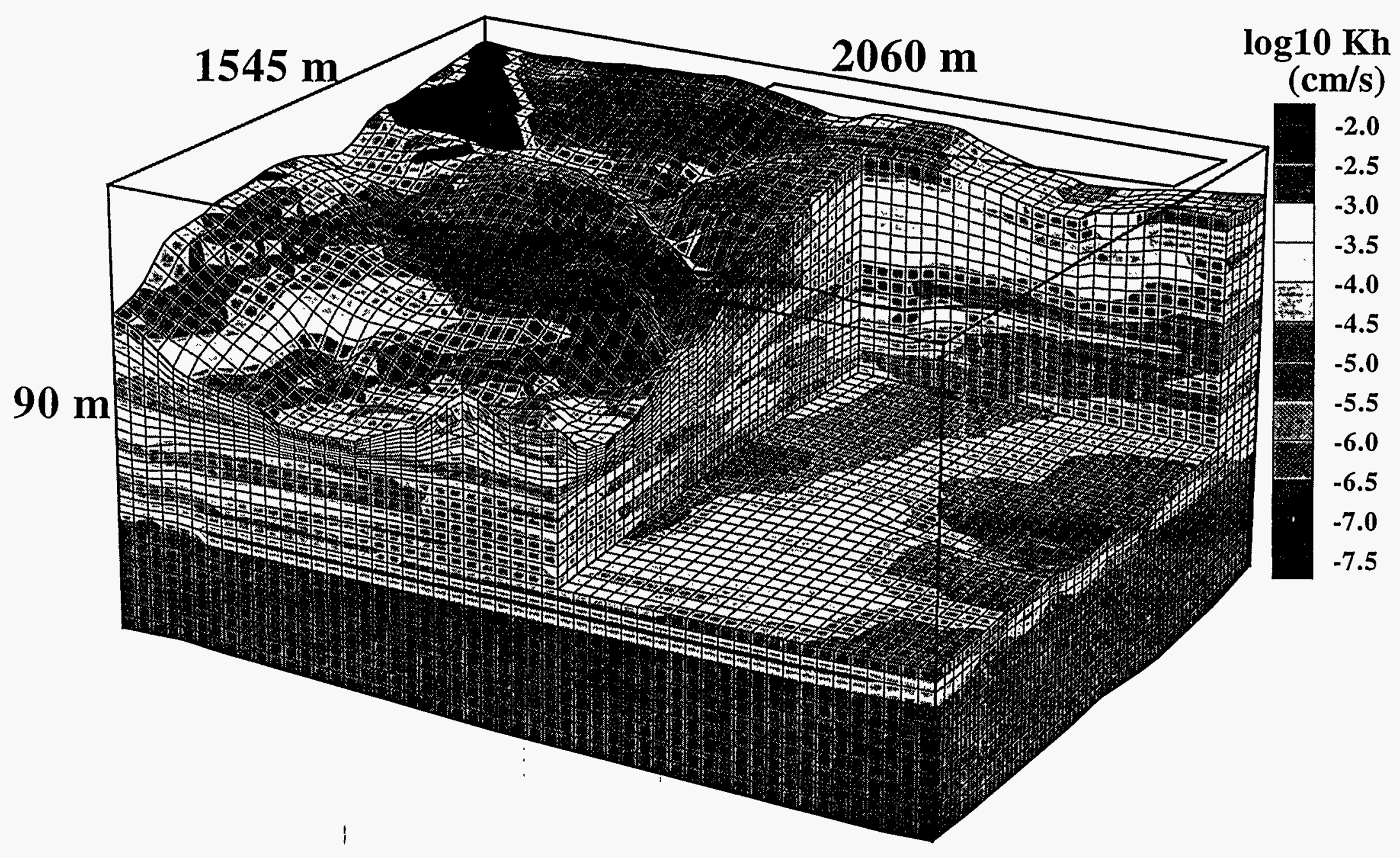




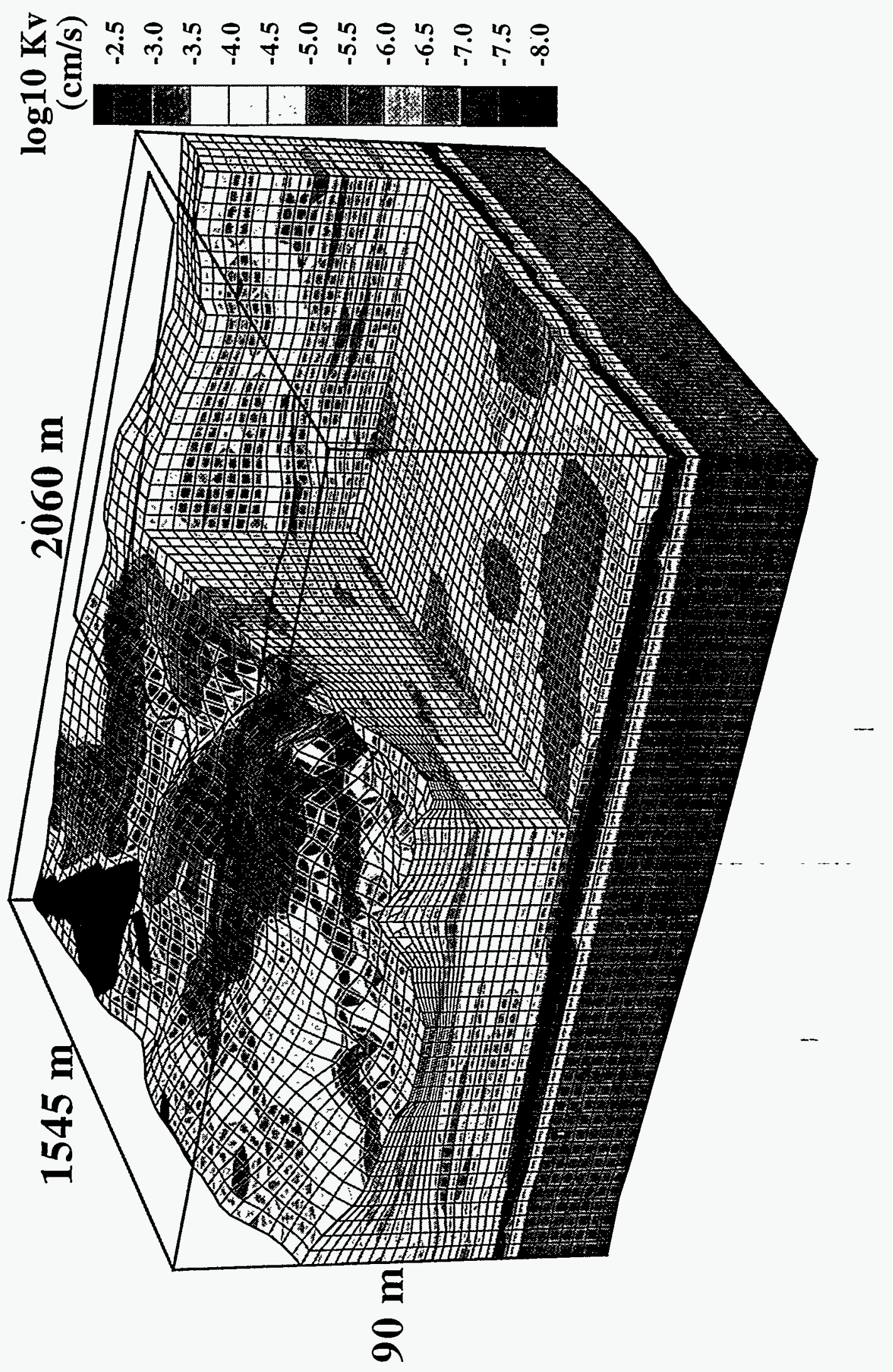




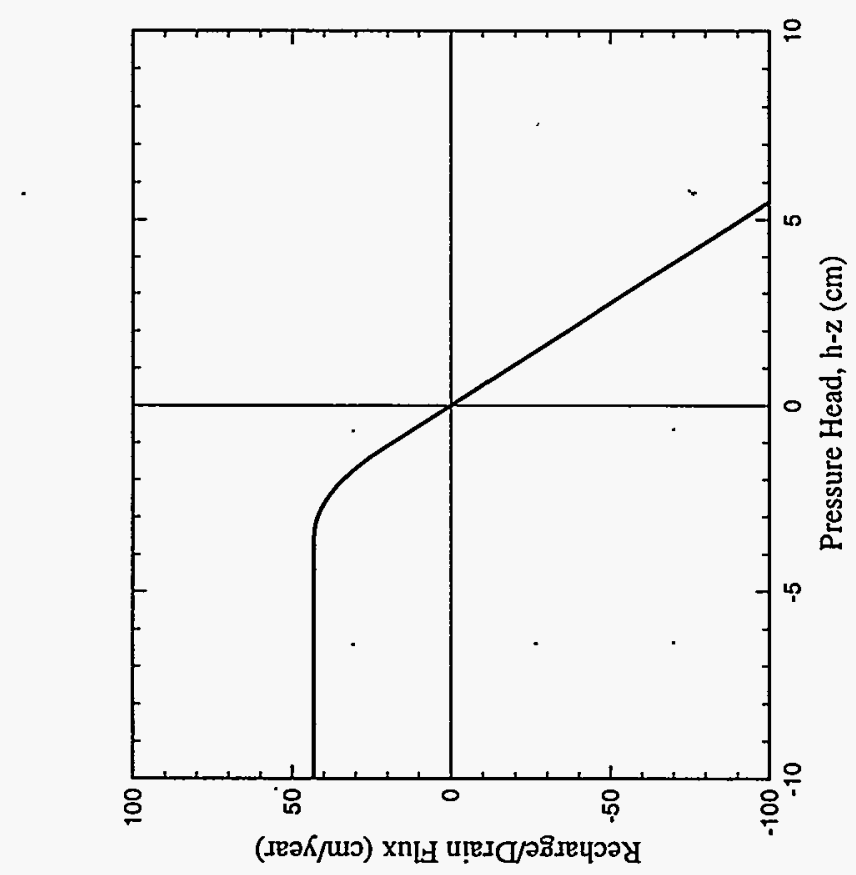




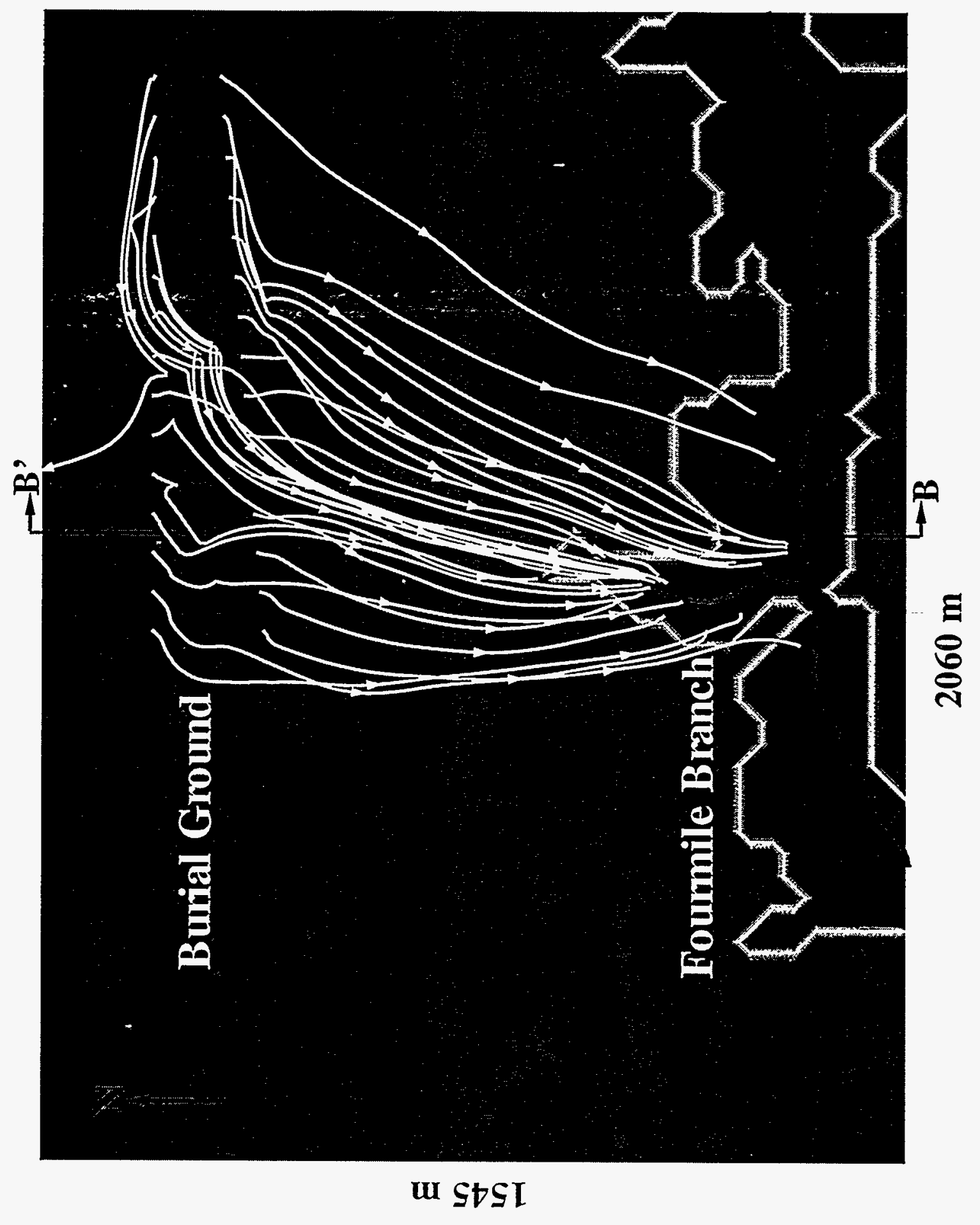




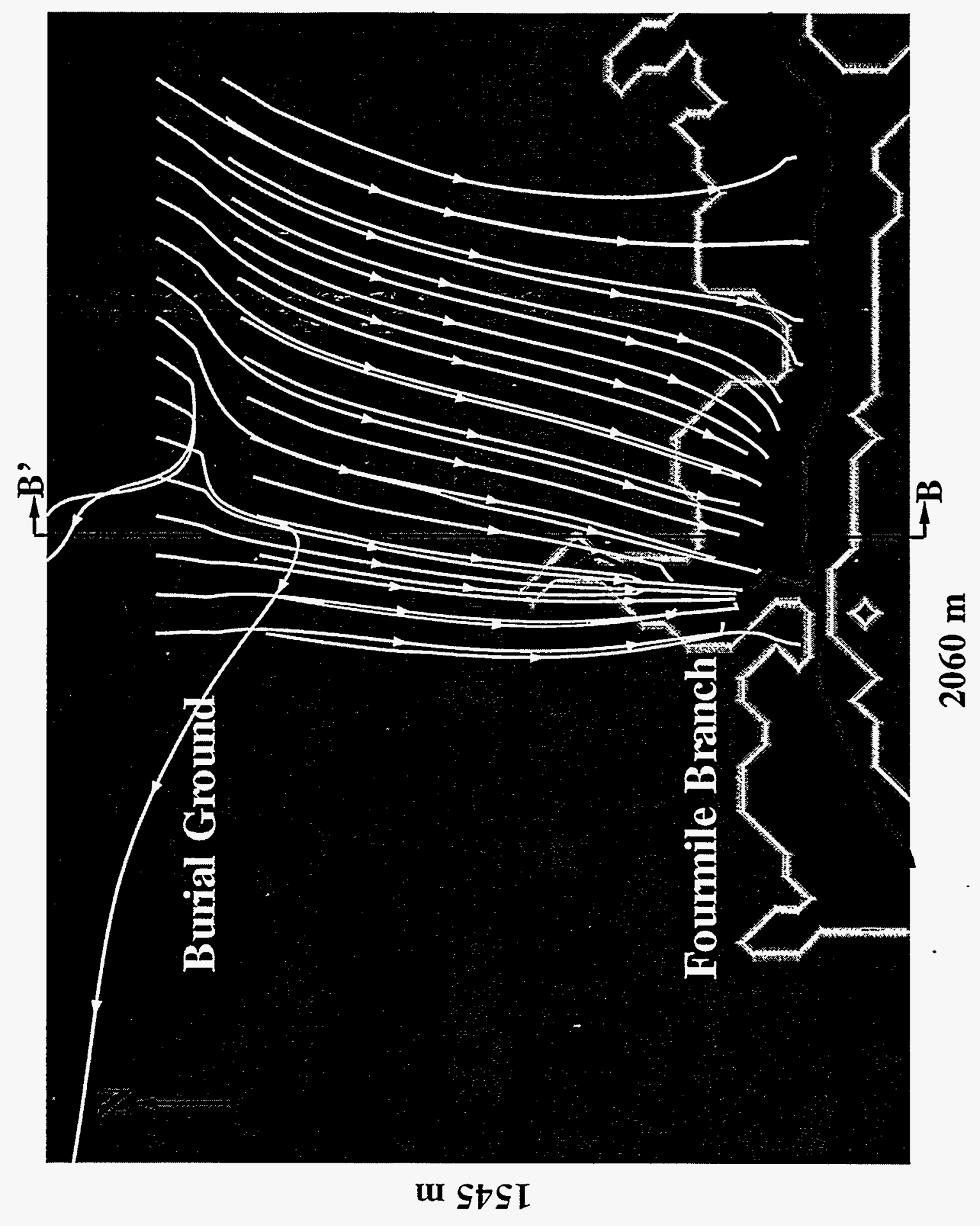




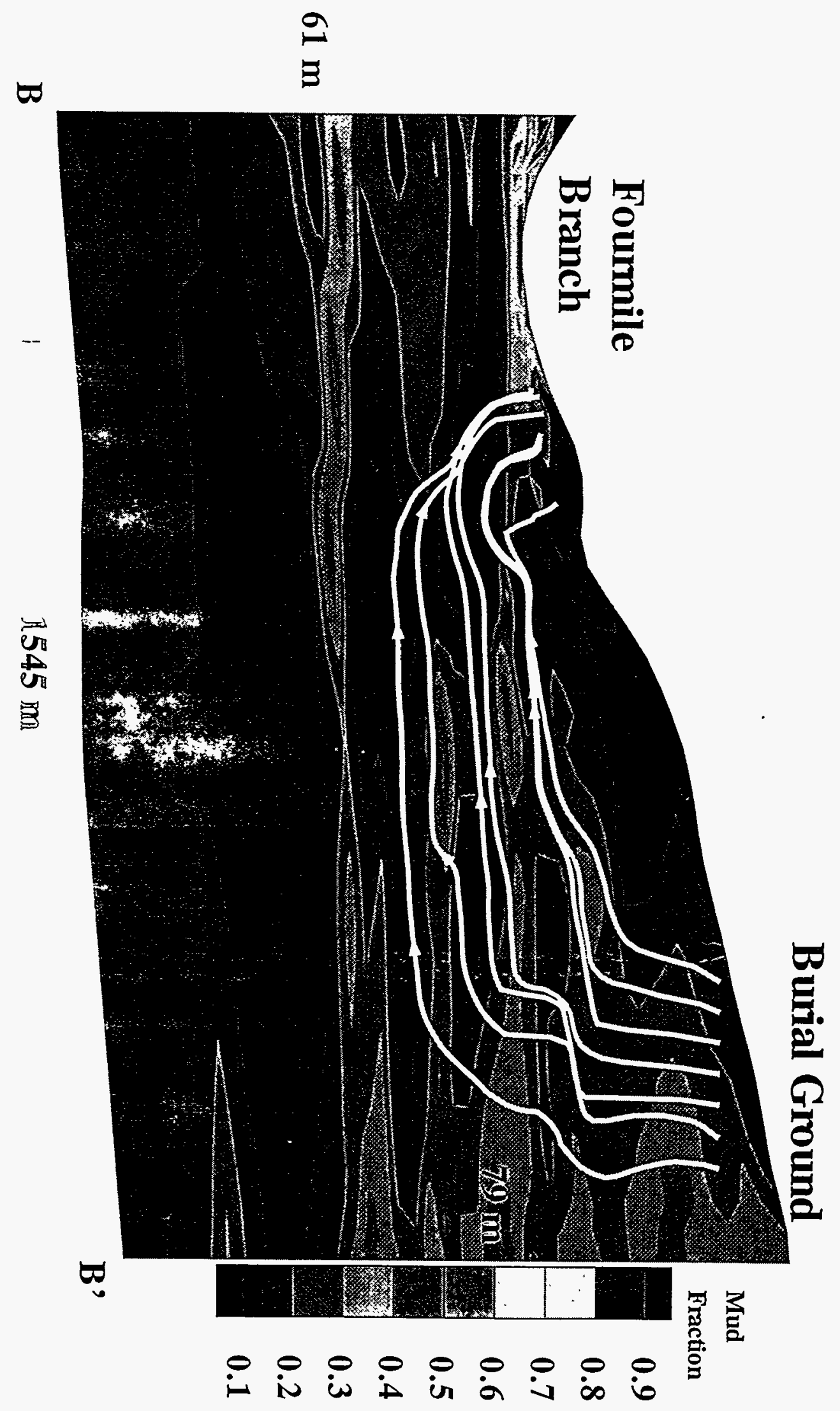




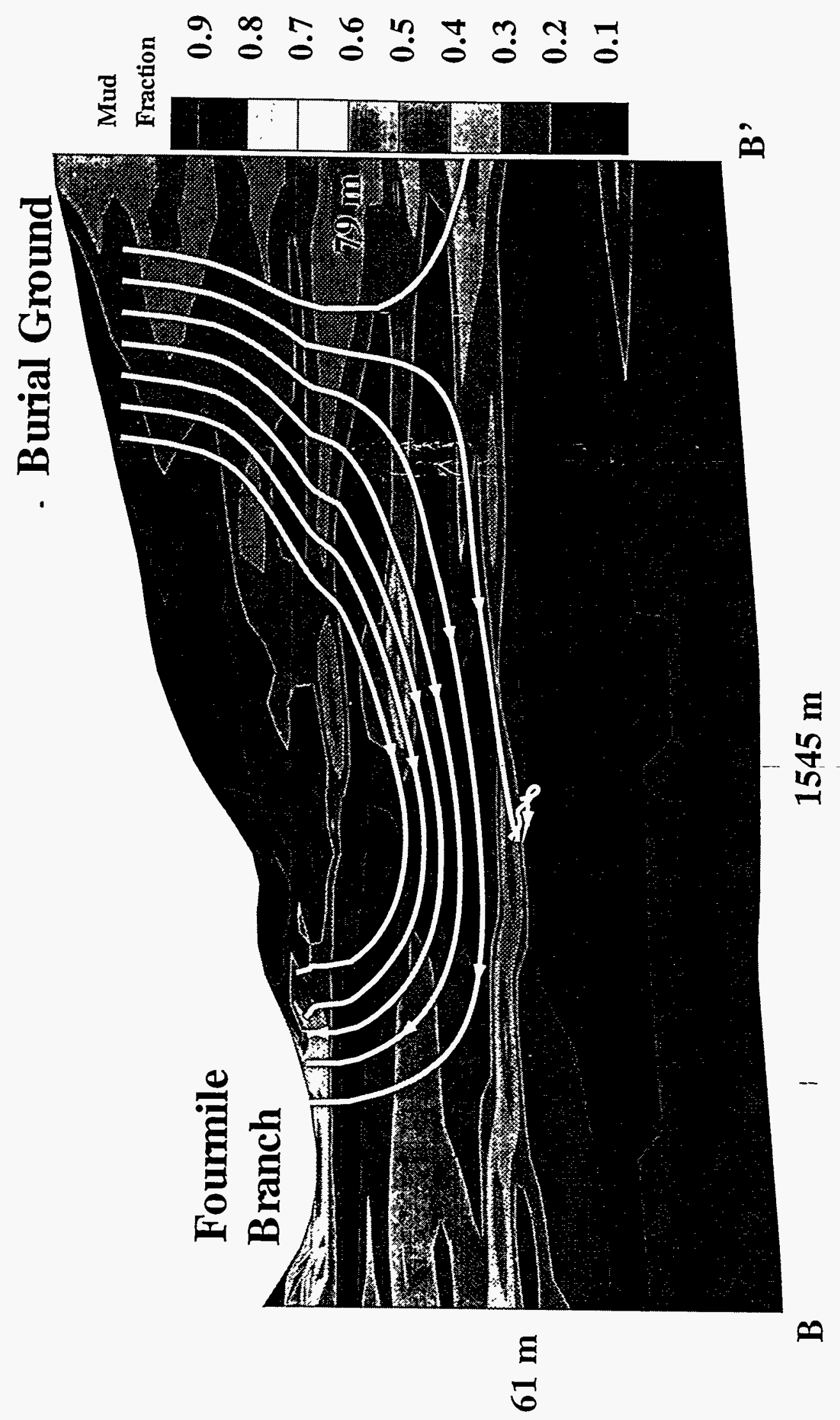

